\title{
Writings, Emotions, and Oblations: The Religious-Ritual Origin of the Classical Confucian Conception of Cheng (Sincerity)
}

\author{
Jinhua Jia ${ }^{1,2}$ \\ College of Humanities, Yangzhou University, Yangzhou 225009, China; jhjia@um.edu.mo \\ Department of Philosophy and Religious Studies, University of Macau, Macau SAR, China
}

check for updates

Citation: Jia, Jinhua. 2021. Writings, Emotions, and Oblations: The Religious-Ritual Origin of the Classical Confucian Conception of Cheng (Sincerity). Religions 12: 382. https://doi.org/10.3390/rel12060382

Academic Editor: Xiaohuan Zhao

Received: 6 May 2021

Accepted: 21 May 2021

Published: 26 May 2021

Publisher's Note: MDPI stays neutral with regard to jurisdictional claims in published maps and institutional affiliations.

Copyright: (c) 2021 by the author. Licensee MDPI, Basel, Switzerland. This article is an open access article distributed under the terms and conditions of the Creative Commons Attribution (CC BY) license (https:// creativecommons.org/licenses/by/ $4.0 /)$.

\begin{abstract}
Cheng 誠 (sincerity) is one of the primary concepts in the Confucian tradition as well as Chinese intellectual history. Its rich implications involve dimensions of religion, ritual, folk belief, ethics, psychology, cosmology, metaphysics, aesthetics, and literature. In the Confucian classics, cheng is described as the "Dao of heaven"; humans through cultivation can reach the mysterious state of "the utmost sincerity functioning as spirits" and thus can "assist the transforming and generating power of heaven and earth." Because of cheng's rich, sacred, and mysterious implications, it has been regarded as the most difficult and perplexing of Chinese concepts. Scholars have long studied cheng mainly from the perspective of philosophy to analyze its ideological conceptions in the Confucian classics, resulting in fruitful and inspiring interpretations. However, because they have not traced the origin of cheng to its rich religious, ritual, and literary sources, their interpretations have been unable to answer the question: why is cheng covered with such a mysterious veil? In recent decades, some scholars have started exploring cheng's relationship with ancient religious beliefs and rituals, but so far a comprehensive examination of the religious-ritual origin of this significant concept remains lacking. To discover cheng's mysterious origins, we must apply a synthetic approach of etymological, religious, philosophical, and literary studies. Drawing upon both transmitted and excavated texts, this essay first analyzes the graphic-phonetic structure and semantic implications of the character cheng 成 (completion), which was the character cheng's 誠 early form. It then examines the rich meanings implied in both characters related to sacrificial-divinatory rituals, including invoking the spirits with sincere writings, emotions, and oblations, in order to seduce them to descend and enjoy the offerings, as well as perfectively completing the human-spirit communication. Finally, the essay discusses how those religious beliefs and ritual ceremonies evolved into Confucian ethical values and aesthetic concepts, thus lifting the mysterious veil from cheng.
\end{abstract}

Keywords: Cheng 誠; cheng 成; sincerity; completion; religion; ritual; Classical Confucianism; literature

\section{Introduction}

Cheng 誠 (sincerity) is one of the primary concepts in the Confucian tradition as well as Chinese intellectual history. Its rich implications involve dimensions of religion, ritual, folk belief, ethics, psychology, cosmology, metaphysics, aesthetics, and literature. In the Confucian classics, cheng is described as the "Dao of heaven"; humans through cultivation can reach the mysterious state of "the utmost sincerity functioning as spirits" 至誠如神 and thus can “assist the transforming and generating power of heaven and earth" 贊天地之化育 (Mencius, 4A12; Zheng and Kong 2000, $53.1689 \mathrm{~b}, 1691 \mathrm{a}-\mathrm{b}, 1693 \mathrm{a}) .^{1}$ Because of cheng's rich, sacred, and mysterious implications, it has been regarded as the most difficult and perplexing of Chinese concepts (Zhang 1983, p. 133; Munro 1988, p. 177), being translated variously as "sincerity," "realness," "reality," "truth," "integrity," "creativity," "force," "perfection," or simply transliterated as "cheng." 2

Scholars have long studied cheng mainly from the perspective of philosophy to analyze its ideological conceptions in the Confucian classics, resulting in fruitful and inspiring interpretations. However, because they have not traced the origin of cheng 
to its rich religious, ritual, and literary sources, their interpretations have been unable to answer the question: why is cheng covered with such a mysterious, sacred veil?

In recent decades, however, some scholars have started exploring cheng's relationship with ancient religious beliefs and rituals. Li Zehou indicated that cheng was originally an important emotional factor and mental state in ancient $w u$ 巫 (shaman) activities (1999, p. 61). This view was further developed by other scholars (Zhong 2013, pp. 12-20; M. Chen 2009, pp. 103-28). Ji Zhichang proposed that the concept of cheng developed from the rites of fast in ancient sacrificial rituals (Ji 2000, pp. 1084-92). Mark Csikszentmihalyi also described cheng as a kind of spiritual attitude in religious rituals (Csikszentmihalyi 2009, pp. 519-42). Sato Masayuki analyzed the appearances of cheng in the Liji 禮記 (Records of Ritual) and identified some of them as referring to a sincere attitude toward spirits and sacrificial rituals (Sato 2005, pp. 215-44). Although these scholars have presented some initial, insightful views for studying cheng from a new perspective that could help lift its mysterious veil, so far a comprehensive examination of the religious-ritual origin of this significant concept remains lacking.

The actual performance of $w u$-shamanistic activities in the pre-historical era is difficult to describe specifically because of insufficient evidence. Many early sources, however, indicate that in the official dimension, the ancient $w u$-shamanistic culture became ritualized during the Zhou dynasty and developed into a set of sacrificial rituals to the ancestral and natural spirits (Li 1999, pp. 34-40; L. Chen 2009, pp. 29-37). At the same time, in the folk dimension $w u$-shamanistic activities continued to flourish in various forms of ceremonies and techniques (Harper 1999, pp. 813-84; Li 2006a, 2006b). In both dimensions, the most important ceremonial procedure was to invoke the spirits with emotions, words, writings, music, dances, and offerings, in order to seduce them to descend and enjoy the sacrificial feasts and bestow blessings. This kind of ceremonial procedure is seen in numerous transmitted and excavated texts, especially in literary works because the ritual was accompanied by dancing, singing, and invoking. For example, $\mathrm{Xu}$ Shen defined $w u$-shaman as being "able to serve the formless and invoke spirits to descend with their dance" 能事無 形，以舞降神者 (Xu 1963, p. 100a), ${ }^{3}$ the “formless" referring to spirits. The Chu songs (Chuci 楚辭) of the Warring States period, especially the entire series of the "Nine Songs" ("Jiuge" 九歌), vividly describe the ritual performance of the interaction between the wu-shaman and various gods/spirits (Hawkes 1985, pp. 42-51; Zhou 1986; Sukhu 2012, pp. 75-85). The concept of cheng was originally connected to this kind of ritual performance, which is the main reason for its sacred-mysterious luster.

In early China, there was no demarcation between philosophy, religion, literature, and so forth. All these dimensions were inter-related and cross-fertilized. To discover cheng's mysterious origins, therefore, we must apply a synthetic approach of etymological, religious, philosophical, and literary studies. Drawing upon both transmitted and excavated texts, in this essay I first analyze the graphic-phonetic structure and semantic implications of the character cheng 成 (completion; hereafter marked as cheng ${ }^{1}$ ), which was the early form of the character cheng 誠 (sincerity; hereafter marked as cheng ${ }^{2}$ ). Then, I examine the rich meanings implied in cheng ${ }^{1}$ and cheng ${ }^{2}$ related to sacrificial rituals, including invoking the spirits with sincere writings, emotions, and oblations, in order to seduce them into descending and enjoying the offerings, as well as perfectively completing the human-spirit communication. Finally, I discuss how these religious beliefs and ritual ceremonies evolved into Confucian ethical values and aesthetic concepts.

\section{Cheng's Early Form and Implications}

Scholars have sighed from being unable to trace the origin of the character cheng ${ }^{2}$ because it is not seen in either the oracle bone or bronze inscriptions, and it also seldom appears in pre-Warring States texts. However, as with many Chinese characters 
whose categorical constituents—such as yan 言 (word), xin 心 (heart, mind), shui 水 (water), $m u$ 木 (wood), and so on-were later additions, the original graph of cheng $^{2}$ was cheng ${ }^{1}$ without a yan-word constituent. This etymology is clearly seen in the Zhongyong 中庸 (Doctrine of the Mean): "Sincerity means self-completion. ... Sincerity does not merely complete oneself but also completes things" 誠者，自成也 ... 誠者，非自成己而已也，所以成物也 (Zheng and Kong 2000，53.1694a). In the early classics, these two characters were commonly used interchangeably. For example, in a poem from the Shijing 詩經 (Classic of Poetry, no. 188), we read, "If it is true (cheng ${ }^{1}$ ) you are not influenced by her riches, you still are so by the difference" 成 不以富, 亦祇以異. ${ }^{4}$ Then, when the Analects (12.10) cites these lines, cheng ${ }^{1}$ (true) is written as cheng ${ }^{2}$. In other early texts, such as the Mozi 墨子 (Master Mo Di), Hanfeizi 韓非子 (Master Han Fei), and Huainanzi 淮南子 (Master Huainan), we see the same interchange between the two characters (Sun 2001, 12.441; Chen 2000, 8. 552, 554; He 1998, 3.262). Furthermore, according to modern scholars' reconstruction of old Chinese, both characters share the same initial consonant and final vowel. For example, Zheng Zhang Shangfang has reconstructed both as *djey (Zheng Zhang 2003, p. 288), while William H. Baxter and Laurent Sagart have reconstructed them as *[d]ey (Baxter and Sagart 2014, pp. 12-13). Because cheng $^{1}$ is both the phonetic and semantic, it should be the etymon for cheng ${ }^{2}$ as well as its early form.

In the OBI, cheng ${ }^{1}$ comprises $x u$ 戊 (a kind of axe-weapon) and gun | (stick; Guo 1979-1983, p. 4905, no. 39503; Xu 1998, pp. 1552-53). Many scholars have indicated that in ancient times, huge axe-weapons such as $x u, w u$ 戊, $q i$ 戚, or yue 戌 might have been used as clan insignias, command symbols, or ritual weapons (Ding 1956, pp. 93-99; Tang 1977, July 14; Qiu 1978, pp. 165-66; Boltz 1994, p. 48). These weapons were used in rituals to symbolize the sanctioned triple power of religion, polity, and military. For example, the jade axes from the Liangzhu 良渚 culture (ca. 3300-2000 BCE) were carved with spirit face motifs (Su 1994, p. 249), while the bronze yue-axes excavated from the Shang-dynasty tomb in Yidu 益都, Shandong province, present similar motifs (Shandong Province Museum 山東省博物館 1972, pp. 17-30). King Wu of Zhou (r. ca. 1046-1043) held a yellow yue-axe at the ritual of reporting to heaven and the ancestors his victory of conquering the Shang (Huang 1995, pp. 447-53). In the Zhou-dynasty dance performance of sacrificial rituals, "the sovereign holds shield and axe standing on his dance position" (Zheng and Kong 2000, 49.1577a). Xu is also used interchangeably with cheng ${ }^{1}$ or cheng ${ }^{2}$, such as in a record in the Huainanzi, "Xu is cheng" 戌爲成 (He 1998, 3.262), or a record in the Yupian 玉篇 (Jade Volume), “Xu is cheng"” 戌, 誠也 (Hu 1989, 30. 5883-84). Xu Shen interpreted cheng ${ }^{1^{\prime}}$ s component of gun | as meaning "to connect the high and the low" 上下通也 (Xu 1963, p. 33a). The high refers to heaven and divinities, and the low refers to earth and humans. If $\mathrm{Xu}$ Shen's interpretation can be trusted, cheng $^{1^{\prime}} \mathrm{s}$ early meaning may have been the connection and communication between humans and spirits in shamanistic-religious rituals. However, even if we do not adopt Xu Shen's interpretation, as a ritual weapon cheng ${ }^{1}$ was still connected to rituals aimed at communicating with spirits.

As mentioned above, the most important ceremony among the sacrificial rituals involved seducing the spirits to descend to enjoy the offerings and bestow blessings. This ceremony was closely connected to the concept of cheng ${ }^{1}$. For example, among the manuscripts excavated from the tombs of the Chu state in the Warring States era, some records involve cheng $^{1}$ as follows:

(1) The sacrifice to kin father is completed. The sacrifice to kin mother is completed. 親父既成. 親母既成.

(2) The sacrifice to the Great One, Earth God, Director of Destiny, Director of Calamity, Great Water, Two Heaven's Sons, and Spirit of Mount Wei have all been completed. 大, 后土, 司命, 司禍, 大水, 二天子, 峗山既皆成.

(3) The sacrifice to the lord of the ancestral temple is completed. 公主既成.

(4) The sacrifice to the Gate Deity is completed. 門既成. 
(5) Auspicious, the wish is granted. 吉, 既成.

(6) Having completed the sacrifice, the supplicant comes down from the altar to further hold the yan sacrifice. 既成, 攻逾而厭之.

(7) Divining it, auspicious, the wish is granted. 占之，吉. 既成 (W. Chen 2009, pp. 92-93, 275, 277, 397, 398, 416).

In these records, the term "cheng" has been interpreted as "completion of sacrifice and supplication" 祭禱完畢 by Yu (1999, p. 167), as “completion of removing the ghosts" 完成移崇 by Shen (2007, p. 433), and as “the ancestral spirits having enjoyed the sacrifices and offerings" 神祖歆享其祀 and the supplications and wishes having been granted by Li (1993, p. 441). According to these interpretations, cheng ${ }^{1}$ refers to the completion of the sacrificial-divinatory ceremonies by which the ancestral spirits, heavenly gods, or terrestrial deities were invoked to descend and enjoy the offerings, the wishes of the supplication and divination were granted, and the human-spirit communication was completed $\left(\right.$ cheng $\left.^{1}\right)$. The first record describes the sacrifice to deceased ancestral spirits; the second to the Great One, Earth Deity, Fortune God, Disaster God, Flood Deity, Two Gods of Heaven's Son, and Spirit of Mount Wei; the third to the dominant spirit in the ancestral temple; and the fourth to the Gate Deity. The sixth does not define the specific spirit, while the fifth and seventh describe divinatory ceremonies. In addition, the implication of "cheng" in the fifth and seventh records is the same as in some records of the excavated day books (rishu 日書), which are folk divinatory texts (Li 2006b, pp. 318-29).

Transmitted texts also hold many records that support cheng ${ }^{1}$ s connection with the invocation ceremony. For example, the first stanza of the poem "Wild-Ducks and Gulls" ("Fu Yi" 兒堅) from the Classic of Poetry (no. 248) reads:

The wild-ducks and gulls are on the stream;

The impersonator of the ancestral spirit feasts peacefully.

Your wines are clear;

Your viands are fragrant.

The impersonator of the ancestral spirit feasts and drinks;

Blessings are made complete.

鳥臨在涇, 公尸來燕來寧. 爾酒既清, 爾敎既馨. 公尸燕飲, 福祿來成.

This stanza describes the invocation ceremony held by the Zhou king for hosting a feast for the impersonator, a descendant who served in the place of the ancestral spirit. The ancestral spirit descends into the impersonator and enjoys the feast, finally completing $\left(\right.$ cheng $\left.^{1}\right)$ its blessings to the king. In the Classic of Ritual, when the impersonator completes a sacrificial feast, it is usually accompanied by the line, "The supplicant announces [to the host] that the feast ritual is auspiciously completed" 祝 告利成 (Zheng and Jia 2000a, 42.936a, 46.1023a; 48.1073a). The Zhouli 周禮 (Ritual of Zhou), which records a sacrificial music called the "Grand Blending Music" (Daheyue 大合樂), with nine sections for invoking different gods and spirits, states such: "If playing the music to the sixth section, all the heavenly gods will descend and can be approached, and the sacrificial ritual can be held for them; ... If playing the music to the eighth section, all the terrestrial deities will come out and can be approached, and the sacrificial ritual can be held for them; ... If playing the music to the ninth section, then human spirits can be approached and the sacrificial ritual can be held for them" 若樂六變, 則天神皆降, 可得而禮矣.... 若樂八變, 則地示皆出, 可得而禮矣. ... 若樂九變, 則人鬼可得而禮矣 (Zheng and Jia 2000b, 22. 679a-b, 689b-690a). The annotator Kong Yingda 孔穎達 explained that when one section was completed, the music must be changed; therefore, the Ritual of Zhou names a musical section as bian 變 (change), while the Shangshu 尚書 (Book of Documents) names it as cheng ${ }^{1}$ (completion; Kong and Kong 2000, 5.152, 154). This informs us that using cheng ${ }^{1}$ to name a 
musical section might have originally referred to gods and spirits (or their impersonators) appearing at the end of each section and thus completing each ceremony.

\section{Sincere Writings, Emotions, Oblations, and the Completion of Human-Spirit Communication at Sacrificial Rituals}

Later, the constituent yan-word was added to cheng ${ }^{1}$ to become cheng ${ }^{2}$, whose early implication was still closely connected to sacrificial rituals. In the Records of Ritual, cheng ${ }^{2}$ refers in most cases to the Confucian moral concept of sincerity, but some references still retain its early religious-ritual implications. For example:

As for invocation, sacrifice, and oblation for the spirits and gods, it would lack sincerity and solemnity if these were held without observing the ritual. 禱祠祭祀, 供給鬼神, 非禮不誠不莊.

To exhaust the root and understand the change, this is the genuine state of music; to present the sincere and remove the artificial, this is the principle of ritual. Ritual and music imitate the genuine condition of heaven and earth, attain the virtue of the spirits, and make the spirits of the high and the low descend and rise. 窮本知變, 樂之情也; 著誠去俀, 禮之經也. 禮樂偩天地之情， 達神明之德, 降興上下之神. (Zheng and Kong 2000, 1. 17a, 38. 1301a)

To illumine sincerity for sacrifice. 絜誠以祭祀. (Wang 1983, 7.120)

All these cases show that cheng $^{2}$ carried on cheng $^{1}{ }^{1}$ s relationship with sacrificial rituals, while it further developed additional meanings such as the importance of sincerity in invoking the gods and spirits to descend in order to complete the rituals.

The rich religious-ritual implications of cheng can additionally be examined from the four layers of writings, emotions, materials, and completion of the human-spirit communication, elaborated as follows.

\subsection{The Layer of Writings}

During sacrificial rituals, important performances involved delivering sincere invocations to invoke the spirits. According to the Ritual of Zhou, the grand supplicant (taizhu 太祝) was responsible for composing and reciting six kinds of invocation (li$u z h u$ 六祝) and six kinds of invocation (liuqi 六祈) to serve the gods and spirits, the former for invoking blessings, and the latter for warding off calamities (Zheng and Jia 2000b, 25.774a-780a). In the Classic of Ritual, we see numerous records of concrete invocations, prayers, laments, prognostications, and so forth (Zheng and Jia 2000a, 43.949b-966a, 47.1039b, 48.1058b). Because these ritual classics are now generally regarded as having been completed during the period of the Warring States to the early Han, these excessively neat, detailed records may contain later modifications. We do, however, have numerous actual writings of invocation and prayer in oracle bone inscriptions, bronze inscriptions, transmitted texts, and excavated manuscripts. These include a large number of the most refined literary works, such as the many poems included in the Classic of Poetry and the Chu songs (Chuci 楚辭).

Here I use as an example the writing of the Jade Plaque of Qin Yin Praying for Healing Illness 秦駰禱病玉版, a text excavated at Mount Hua 華山 (in present day Shaanxi). Qin Yin was probably King Huiwen of Qin (r. 325-311 BCE), who prayed to the spirits of Mount Hua, the Great One, and the Great General for healing his serious illness (Li 2000, pp. 41-45; Lian 2001, pp. 49-57; Zhou 2001, pp. 217-32). This text is a refined, rhymed literary work, which mixes tetrasyllabic lines, the dominant poetic form in the pre-Han period, with lines of varied syllabics. It is virtually a verse of the $f u$ 賦 genre that originated in the late Warring States and flourished in the Han dynasty. The text, with about 300 characters, can be divided into four sections. The first expresses the king's sad feelings about his illness:

In the tenth month, the beginning of winter,

The retrograde atmosphere is fading and bleak. 
My body is suffering from a serious illness,

Which makes me very sad and worried.

I toss and turn, restlessly and repeatedly,

But my illness shows no sign of recovery.

People don't know why, and I also don't know why

-it is never over.

I am desperate and find no way out,

Sighing deeply with my sorrows.

孟冬十月，厥氣敗调. 余身遭病，爲我戚憂. 忆忆反側，無間無疹. 衆人弗知，余

亦弗知, 而靡有定休. 吾窮而無奈之何, 永嘆憂愁. (Li 2006b, pp. 343-61)

This section comprises mainly tetrasyllabic lines, which are neatly rhymed with the you 幽 rhyme group, just like a typical poem in the Classic of Poetry. It starts by describing a fading scene of early winter, which effectively leads to the expression of the king's sorrowful feelings about his serious illness. The next section narrates how the king intends to pray to all the heavenly gods, territorial deities, and ancestral spirits, but does not know the ways to do so because the fall of the Zhou court had caused the loss of the ritual codes. In the third section, the king professes to the gods that he has never committed any crimes. Finally, the king prays to the gods and spirits of Mount Hua, the Great One, and the Great General, promising a long list of offerings if those spirits will help him recover from his illness. The text thus sincerely describes and expresses the king's painful illness, sorrowful feelings, and bitter supplication to the gods/spirits.

The purpose of the sincerity presented in supplicatory writings was to gain $x$ in 信 (trustworthiness, faithfulness) from the gods and spirits. For example, the Zuozhuan 左傳 (Zuo's Commentary) records:

The so-called Dao is to be loyal to the people and trustworthy to the gods.

The ruler thinks about benefiting the people-this is loyalty; the supplicant and scribe present correct writings to the gods-this is trustworthiness 所謂 道，忠于民而信于神也. 上思利民，忠也; 祝史正辭，信也. (Huan 6, 706 BCE)

The supplicant and scribe present trustworthy writings to the spirits and gods without words of qualm. 其祝史陳信于鬼神, 無愧辭. (Xiang 27; 546 BCE)

Here, xin (trustworthiness) in both records clearly refers to presenting sincere supplicatory writings to attain the trust of the gods and spirits. Although the term $c i$ 辭 refers to both words and writings in classical Chinese, supplicatory "ci" was usually written down. As the Mozi tells us, services to the gods and spirits were so significant that they must be written on bamboo and silk or engraved on bronzeware and stone, so as to be transmitted to later generations. 故書之簡帛 ... 琭之盤孟, 鏤之 金石以重之 (Sun 2001, pp. 237-38).

In contrast, if the invocation were not sincere, the gods and spirits not only would not bestow any blessings but would also exercise a bad influence. For example, Duke Xian of Jin's 晋獻公 heir Shensheng 申生 committed suicide under the slanders of Concubine Li; later his brother Duke Hui of Jin 晋惠公 reburied him with the correct ritual, but his body emitted a foul smell. The people of Jin then said, "The correct ritual was not accepted by the deceased because the supplication (xin) was not sincere" 貞爲不聽，信爲不誠 (Lai 2000, pp. 438-41). Here, xin is used directly to refer to the supplicatory writing recited by the supplicant during the funeral ritual.

The character xin 信 comprises the two graphs ren 人 (human) and yan 言 (word), meaning that a human's words are trustworthy and faithful. Xin's early implication might have been the use of words to gain the trust of the gods and spirits, as seen in the above citation that directly uses xin to refer to supplication. Xu Shen explained xin as cheng ${ }^{2}$ and cheng $^{2}$ as $x i n$ (Xu 1963, p. 52a-b); thus, the two are virtually synonyms. With the addition of the constituent yan (word), cheng $^{2}$ also referred to using sincere words/writings to gain the trust of the gods and spirits in order to supplicate them to 
descend and enjoy the offerings. As a result, cheng $^{2}$ and $x$ in were often used together or else formed the compound chengxin 誠信 to indicate sincere and trustworthy supplicatory words and writings. For example, the Records of Ritual states: "Therefore, when the virtuous person holds sacrificial rituals, he presents his sincere-trustworthy [supplicatory writings]" 是故賢者之祭也, 致其誠信 (Zheng and Kong 2000, 49. 1571a$1573 b)$.

\subsection{The Layer of Emotions}

The second layer embedded in cheng's relationship with sacrificial ritual is psychological emotion and attitude of sincere reverence (jing 敬) and fear (wei 畏) toward the gods/spirits. Although the character cheng $^{2}$ comprises the categorical constituent of yan (word), not xin (heart-mind), psychological sentiment is also an extremely significant factor. According to the Classic of Ritual, during a sacrificial ritual, from the king of Zhou to the common people, everyone must fast and dress up, reverently and repeatedly kowtowing to the impersonator of ancestral spirits and exhorting him to enjoy the offerings, even though the impersonator would be much younger (usually played by a grandson) and lower in social position than the ritual hosts (Zheng and Jia 2000a, 44.967a-46.1035b). The Guoyu 國語 (Discourses of the States) records Guan Shefu's 觀射父 words on sacrificial ritual, saying: "Who dares not be fearful in serving the many gods?" 其誰敢不戰戰競競, 以事百神, and “Who dares not fast solemnly and reverently devote oneself to the gods?" 其誰敢不齊肅恭敬, 致力於神 (Lai 2000, 18.804). According to the Analects (3.12):

Confucius made sacrifice to the ancestral spirits as if the spirits were present, and made sacrifice to the gods as if the gods were present. The master said, “If I cannot take part in a sacrifice, it is as if I did not sacrifice." 祭如在, 祭神 如神在. 子曰: “吾不與祭, 如不祭.”

When Confucius took part in a sacrifice, he was always sincerely reverent as if the spirits and gods were indeed present. Confucius had a famous saying of "showing reverence to the spirits and gods while keeping distance from them" 敬鬼神而遠 之 (Analects, 6.22); his disciple Zizhang 子張 said, "One must think about reverence when making the sacrifice" 祭思敬 (Analects, 19.1). According to the Records of Ritual, sacrificial rituals must "offer one's devoted reverence" 與其忠敬, and "to do one's utmost is called reverence" 盡之謂敬 (Zheng and Kong 2000, 49.1571a, 1573a-b). The same ritual classic also contains many more discussions of the importance of jing (reverence) in sacrificial rituals. As a result, cheng ${ }^{2}$ and jing are often used together or else combined to form the compound chenging 誠敬 (sincere reverence). For example, the Records of Ritual states that a superior person's (junzi 君子) attitude toward ritual is “to present one's reverence, sincerity, and submission" 致其敬而誠若. Later, the literary theorist Liu Xie 劉勰 (b. ca. 465) said this: “The style of supplicatory writing must be sincere and reverent. ... Ban Gu's writing for the sacrificial ritual to Mount Zhuoxie displays sincere-reverence of supplication" 祈禱之式, 必誠以敬.... 班固之 祀溷山，祈禱之誠敬也 (Fan 1958, pp. 176-77).

\subsection{The Layer of Materials}

The third layer embedded in cheng's relationship with sacrificial ritual has to do with materials in offering abundant oblations to the gods and spirits. It is also essential to completing the sacrificial ritual that the oblations be sincerely presented and the spirits (impersonators) be fully filled and satisfied.

The Records of Ritual says, "The sacrifice to heaven held in the suburb uses the particular victim (calf), and the sacrifice to earth uses the great victim (ox).... This is to value the implication of sincerity. ... To use a calf is to value sincerity" 郊特牲 而社稷大牢，... 貴誠之義也.... 用犢，貴誠也. The sacrifice to heaven is more significant than the one to earth, so why does the ritual use smaller victim? According to Zheng Xuan's annotation, a calf has not yet known the distinction between male and 
female and therefore represents purity and sincerity (Zheng and Kong 2000, 25.892a; 26.927a). Guan Shefu's discourse on ritual mentioned above further indicates that to offer victims in a sacrificial ritual is "to connect to spirits with sincerity" 接誠于 神 (Lai 2000, 18.803). The numerous manuscripts of sacrificial records excavated at Baoshan 包山, Wangshan 望山, Geling 葛陵, and so on all record in detail the victims, wines, and foods presented to the spirits in sacrifices (W. Chen 2009, pp. 91-117, 27185, 395-445). In the Jade Plaque of Qin Yin Praying for Healing Illness discussed above, the king of Qin used various jade articles to pray to the spirit of Mount Hua and promised that if his illness was healed, he would offer the spirit the sacrificial victims of ox, sheep, and pig, as well as artificial chariots, horses, and human figures. The Classic of Ritual lists varied kinds of abundant offerings, stating how foods are "filling the tripods" 實于鼎, “filling the basket" 實于篚, “filling the bowl" 實于豆, and "filling the plate" 實于盤 before the ceremony. The text also describes how the impersonator is urged to eat and drink during the ceremony, from "one time" to the maximum of "fifteen times," during which the impersonator "pronounces he is full" 告飽 again and again, while the supplicant urges repeatedly, "Your grand impersonator has not yet been full" 皇尸未實 (Zheng and Jia 2000a, 47.1036a-48.1076a, 49.1077a-50.1133a).

The character shi 實 comprises mian ' (room) and guan 貫 (shell-money, goods), which symbolizes a room full of wealth and thus means richness and fullness $(\mathrm{Xu}$ 1963, p. 150b). In the above cases, shi is used to describe two kinds of activities during a sacrificial ceremony: the first is to fill various food containers with the offerings so as to display the abundant and substantial offerings to the spirit; the second is to urge the impersonator of the spirit to eat and drink so as to make his belly full. The "Thich Tribulus" (Chuci 楚茨) poem from the Classic of Poetry (no. 209) describes a sacrificial ritual to the ancestral spirits hosted by the king of Zhou, vibrantly describing such activities:

\section{Stanza III}

They attend to the furnaces with reverence;

They prepare the trays, which are very large,

Some for the roast meat, some for the broiled.

The consorts are still and reverent,

Preparing the numerous dishes.

The guests and visitors,

Present the cups and drink all round.

Every form is according to ritual propriety;

Every smile and word are as they should be.

The spirits arrive,

And respond with great blessings,

Myriads of years as the reward.

執䤑踖踖, 為沮孔碩, 或燔或多. 君婦莫莫, 為豆孔庶. 為賓為客, 獻酬交錯. 禮 儀卒度, 笑語卒獲. 神保是格, 報以介福, 萬壽做酢.

\section{Stanza V}

The ceremony having been completed,

The bells and drums having informed it,

The filial descendent goes to his place,

And the supplicant makes his announcement,

"The spirits are drunk;

The grand impersonator rises."

The drums and bells escort his withdrawal,

And the spirits thus return.

All the majordomos and consorts

Remove the offerings without delay.

The uncles and cousins 
All stay for the private feast.

禮儀既備, 鍾鼓既戒. 孝孫徂位, 工祝致告: 神具醉止, 皇尸載起. 鼓鍾送尸，神 保聿歸. 諸宰君婦, 廢徹不遲. 諸父兄弟, 備言燕私.

In stanza three, the majordomos and consorts of the royal house reverently prepare foods and drinks and fill them into large containers and dishes, all of which observes ritual propriety. The spirits are invoked to come and bestow blessings upon the king and the royal house. In stanza five, the spirits are full and drunk, and the ceremonies are perfectly completed. These descriptions vividly show how the sumptuous sacrificial feast pleased the spirits, thus "connecting to gods with sincerity." ${ }^{5}$

\subsection{The Layer of the Completion of Human-Spirit Communication}

The fourth layer embedded in cheng's relationship with sacrificial ritual is the completion $\left(\right.$ cheng $\left.^{1}\right)$ of human-spirit communication. As cited above, the seven records from newly excavated manuscripts and many records from transmitted texts use the term cheng ${ }^{1}$ to describe the completion of the spirits' descending and responding to the hosts' sacrificial ceremonies. The poem "Wild-Ducks and Gulls" cited above also describes how "the impersonator of the ancestral spirit feasts and drinks; Blessings are made complete $\left(\right.$ cheng $\left.^{1}\right) . "$

Cheng $^{2}$ also carries forward this meaning. For example, the Annals of Sire Lü records such: "If being sincere, then the spirits respond to humans" (Chen 2001, 26.1697). The Records of Ritual attributes the following discourse to Confucius:

How abundantly do the spirits and gods display their powers! We look for them but do not see them; we listen to them but do not hear them. Yet they are embodied in things, and there is nothing without them. If all the people in the world fast purely and dress up solemnly to attend the sacrifices, then like overflowing water, the spirits seem to be over our head and on our right and left. It is said in the Classic of Poetry, "As for the arrival of the spirits, you cannot surmise; but how can you be weary of the sacrifice!" Such is the manifestness of what is subtle and the impossibility of repressing sincerity. 鬼神之爲德，其盛矣乎! 視之而弗見, 聽之而弗聞, 體物而不可遺. 使天下之 人，齊明盛服，以承祭祀，洋洋乎如在其上，如在其左右. 詩曰: “神之格思，不 可度思, 知可射思.” 夫微之顯, 誠之不可拾如此夫! (Zheng and Kong 2000, 52.1675a-1676a)

Zheng Xuan explained the word cheng $^{2}$ (sincerity) at the end of the discourse as referring to the spirits being real (Zheng and Kong 2000, 52.1676a), an interpretation that many scholars have followed. In fact, this discourse is talking about the importance of holding sacrificial rituals with a sincere attitude. First, it indicates that although the spirits are formless and soundless, if humans attend the rituals sincerely, the spirits will be moved to come and make their presence known. It then cites lines from the Classic of Poetry to state that even though it is difficult to know for certain that the spirits have arrived, humans should not become weary of the rituals. Lao Szekwang has argued that the word "ge" 格 here denotes both meanings of the spirits "coming to enjoy the offerings" and "communicating with humans" (Lao 2001, pp. 6061). Therefore, here cheng ${ }^{2}$ should be interpreted as being sincere when invoking the spirits to come and thus complete the ceremony of human-spirit communication.

\section{From Religious-Ritual Beliefs to Classical Confucian Ethical-Aesthetic Concepts}

As discussed above, both cheng $^{1}$ and cheng ${ }^{2}$ are related to sacrificial ritual and imply four layers of attitude toward or condition of the gods and spirits: chengxin 誠信, or sincere-trustworthy writings; chengjing 誠敬, or sincere-reverent sentiments; cheng$s h i$ 誠實, or sincere-substantial oblations; and cheng ${ }^{1}$, or completion of human-spirit communication. Indeed, the Records of Ritual describes the "Dao of sacrifice" 祭之道 
as meaning "to present sincere-trustworthy supplications, offer devotional-reverent emotions, and contribute substantial oblations.... Sincere-trustworthy means to do their utmost, and to do their utmost means to be reverent. Being reverent and doing their utmost, then they can serve the gods and spirits" 致其誠信, 與其忠敬, 奉之以 物 ... 誠信之謂盡, 盡之謂敬. 敬盡然後可以事神明 (Zheng and Kong 2000, 25.1571a1573b). Guan Shefu's discourse on sacrificial rituals mentioned above also further describes the sacrificial procedure in four layers of contributing substantial oblations, expressing reverent emotions, presenting sincere invocations, and completing the ritual with the arrival of the ancestral spirits (Lai 2000, 18.804). Both records indeed demonstrate the four layers of cheng $^{1} /$ cheng $^{2}$-related sacrificial rituals.

With this new discussion of the religious-ritual origin of $\mathrm{cheng}^{2}$, we can now more clearly understand its rich and mysterious implications in classical Confucian ethics and aesthetics, which also can be unfolded in four corresponding layers.

\subsection{Chengxin}

We have shown that cheng and xin are synonyms and are often used together to form the compound chengxin. From the Western Zhou to the Spring and Autumn period, xin was already an important virtue, referring to sincere, devoted trustworthiness and faithfulness in a person's or a state's words/writings and conduct (Chen 2006, pp. 335-43; An 2004, pp. 119-21). Confucius listed xin as one of the four subjects he taught his students (Analects, 7.25). In Confucian classics such as the Analects, Mencius, Xunzi, and the Records of Ritual, as well as newly excavated manuscripts, xin appears numerous times, in most cases referring to sincere, trustworthy, and faithful words, writings, and conduct in dealing with interpersonal relationships and cultivating one's moral character. In the Xunzi, the compound chengxin appears three times, all of which refer to ethical-moral virtues, with two of them stating that "sincere trustworthiness functions as the spirits" (chengxin sheng shen 誠信生神 and chengxin ru shen 誠信如神, $3.12,14.3)$. This reminds us of the religious-ritual origin of cheng ${ }^{2}$ and $x i n$ and the close connection between the two.

Moreover, this ethical-moral virtue also developed into a fundamental criterion in Confucian aesthetics. The classical commentary to the Qian 乾 hexagram in the Book of Changes attributes to Confucius the statement, "Refining writings to establish sincerity" 脩辭立其誠, which extended the sincerity and trustworthiness of supplicatory writings to that of a ruler's statements and teachings (Wang and Kong 2000, 1.18a-19b). Liu Xie, however, in citing this statement, returned it to its meaning as a basic feature of supplicatory writings:

Supplicants and scribes present their trustworthiness, relying on the diction of writings.

In general varied writings blossom gorgeously,

but to make the spirits descend must be truthful.

Refining writings to establish sincerity,

There will be no qualms of conscience.

祝史陳信, 資乎文辭.... 凡群言發華, 而降神務實. 修辭立誠, 在於無愧. (Fan 1958, pp. 176-77)

Clearly, Liu Xie was well aware that the connection between writings and sincerity originated from the supplicatory writings for sacrificial rituals, and so he established sincerity-trustworthiness as a fundamental criterion for this kind of writing. Later, Confucian scholars such as Cheng Hao 程影 (1032-1085), Zhu Xi 朱喜 (1130-1200), and others extended this criterion to all kinds of discourses and writings (Li 1986, pp. 95.2445; Wang and Gu 2001, p. 18). 


\subsection{Chengjing}

Both Mou Zongsan and Xu Fuguan, who have paid great attention to the concept of jing (reverence), assert that although jing appears to denote religious piety, it in fact signifies human subjectivity and rationality (Mou 1984, p. 20; Xu 2009, p. 22). Mou and $\mathrm{Xu}$ seem to mix the religious-ritual origin of $j i n g$ with its ethical-psychological extension in Zhou ritual propriety and classical Confucian ethical theory. In sacrificial rituals, with its connection to cheng ${ }^{2}$, jing did denote pietistic emotion and attitude toward heaven and the spirits, as discussed above. This kind of religious emotion and attitude was then extended in Zhou ritual propriety to one's sincere reverence toward elders and superiors (Chen 2006, pp. 343-45). In the Confucian classics, jing developed more ethical and psychological implications, such as sincere reverence toward one's parents and devotional reverence toward one's service (Analects, 2.7, 4.18, 13.19, 15.38; Wang 1988, 20.529-33). As a result, cheng and jing were often used together or combined to form the compound chengiing (sincere reverence). For example, Cheng Hao emphasized that chengjing was the essential moral emotion and attitude for observing all five of the constant virtues (Huang 1846, 13.5a-6b).

\subsection{Chengshi}

From the character shi, with its structure of a room full of wealth, was later derived the meanings of substantialness, actuality, truthfulness, and reality (An 2004, pp. 121-22; Mcleod 2018, pp. 145-50). With its close connection to shi in sacrificial ritual, cheng also derived similar meanings of substantialness, realness, and truthfulness, and was often combined with shi to form the compound chengshi, denoting the meanings of realness and honesty. In the Confucian classics as well as other classics, cheng is frequently used as an adverb to denote the meaning of "really" or "truly." Xunzi used the term chengneng 誠能 to refer to "true talent" (Wang 1988, 11.209, 218). In the statement of the Zhongyong 中庸 (Doctrine of the Mean) that "cheng is the beginning and ending of things, while without cheng there is not a thing" 誠者物之終始， 不誠無物 (Zheng and Kong 2000, 53.1694a), cheng connotes the substantiality and actuality of things. In his Lunheng 論衡 (Doctrines Weighed), Wang Chong 王充 (27-ca. 97 CE) frequently used the compound "shicheng" 實誠, which is the same as "chengshi," to denote the meaning of sincere truth (Huang 1990, 13.609, 19.815, 24.1003; Mcleod 2018).

\subsection{Chengdao 誠道 (The Dao of Sincerity)}

Finally, cheng ${ }^{2}$ developed from meaning the completion of human-spirit communication to meaning the unity of heaven's Dao with humans' Dao. As Mencius said, "Sincerity is the Dao of heaven, and the pursuit of sincerity is the Dao of humans" 誠者, 天之道也; 思誠者, 人之道也 (Mencius, 4A12). The Doctrine of the Mean similarly states, "Sincerity is the Dao of heaven, and the attainment of sincerity is the Dao of humans" 誠者, 天之道也; 誠之者, 人之道也 (Zheng and Kong 2000, 53.1689b). Because Cheng Yi 程頣 and Zhu Xi 朱喜 explicated cheng $^{2}$ as being the "principle of reality" (Zhu 1992, p. 31), many scholars have assumed that classical Confucians regarded cheng as the ontological foundation of all existence. Cheng's and Zhu's explication, however, represented only the neo-Confucian reconception of $\mathrm{cheng}^{2}$. In fact, during the Warring States period it was a common concept that cheng ${ }^{2}$ represented the movement and virtue of heaven. For example, the Heguanzi 鹖冠子 (Master of the Pheasant Cap) states such:

Heaven makes sincerity the virtue of the sun: the sun sincerely emerges and sincerely enters. ... Heaven makes faithfulness the law of the moon: the moon faithfully dies and faithfully grows. 天者誠其日德也，日誠出誠入.... 天者信其月刑也，月信死信生. (Huang 2004, pp. 168-69) 
The regular, constant circulation of the sun and the moon represents the movement of heaven's course (dao) and its virtue of sincerity and faithfulness. A similar statement is also seen in the silk manuscript Jingfa 經法 (The Canon of Law) excavated from Mawangdui (Yates 1997, pp. 80-81). The Xunzi reads as follows:

Heaven does not speak, but people infer its height. Earth does not speak, but people infer its thickness. The four seasons do not speak, but people anticipate them. These things have such constancy because they have utmost sincerity. ... Heaven and Earth are most vast, but without sincerity they could not transform the myriad things. 天不言而人推高焉, 地不言而人推厚 焉, 四時不言而百姓期焉. 夫此有常，以至其誠者也.... 天地為大矣，不誠則不 能化萬物. (Wang 1988, 2.46)

Heaven, earth, and the four seasons never speak, but they demonstrate their sincerity through regular, constant movement, which generates and transforms the myriad things. The Annals of Sire Lü presents similar ideas:

If heaven's movements were not faithful, the year could not complete. If earth's movements were not faithful, grass and trees could not grow. ... Great as heaven and earth are, and as transforming as the four seasons are, they still could not complete things by being unfaithful, let alone human affairs. 天行不信, 不能成歲; 地行不信, 草木不大.... 天地之大, 四時之化, 而 猶不能以不信成物, 又況乎人事. (Chen 2001, 19.1311)

This also describes the regular movements of heaven, earth, and the four seasons as representing their virtue of sincerity and faithfulness while setting a model for human affairs. Reading all these statements together with the two passages from the Mencius and the Records of Ritual cited above, we can see clearly that this was in fact a common natural, cosmological view of the Warring States thinkers, without involving the dimension of an ontological "principle of reality."

Prior to defining sincerity as heaven's Dao, both passages from the Mencius and the Records of Ritual discuss the significance of sincerity in cultivating one's own good virtues and serving one's parents, friends, superiors, and the people. This shows that the authors' concern still lies in the dimension of ethical and political virtues. With its sincere movements and virtues, heaven generates and transforms the myriad things, including human beings. If humans attain cheng (sincerity), chengren 成人 (completion of consummate humanity; Analects, 14.12), and chengwu 成物 (completion of things; Zheng and Kong 2000, 53.1694a) through imitating heaven and cultivating themselves, they are assisting heaven in its work of generation and transformation. Thus, the mysterious veil hanging over cheng has finally been lifted.

Funding: This research received no external funding.

Institutional Review Board Statement: Not applicable.

Informed Consent Statement: Not applicable.

Data Availability Statement: Not applicable.

Conflicts of Interest: The author declares no conflict of interest.

\section{Notes}

1 Translations of all citations from the Mencius are adapted from Lau 1970; translations of all citations from the Records of Ritual are adapted from (Legge 1994).

2 For a summary of these translations and interpretations, see (An 2004, pp. 117-36; 2005).

3 Unless specifically indicated, all translations of citations from Chinese texts in this essay are my own.

4 Translations of all citations from the Classic of Poetry are adapted from (Legge 1994).

5 Jordan Paper cited this poem and other sources to indicate that the sacrificial meal offered to ancestors formed the ritual core of Chinese religion (Paper 1995).

6 Translation adapted from (Hutton 2014, p. 20). 
7 Translation adapted from (Knoblock and Riegel 2000, pp. 500-1).

\section{References}

An, Yanming. 2004. The Concept of Cheng 誠 and Its Western Translations. Dao: A Journal of Comparative Philosophy 4: 117-36. An, Yanming. 2005. The Idea of Cheng (Sincerity/Reality) in The History of Chinese Philosophy. New York: Global Scholarly Publications.

Baxter, William H., and Laurent Sagart. 2014. Baxter-Sagart Old Chinese Reconstruction. Version 1.1. pp. 12-13. Available online: http:/ / ocbaxtersagart.lsait.lsa.umich.edu/BaxterSagartOCbyMandarinMC2014-09-20.pdf (accessed on 15 January 2015).

Boltz, William G. 1994. The Origin and Early Development of the Chinese Writing System. New Haven: American Oriental Society.

Chen, Qiyou 陳奇猷, ed. 2000. Hanfeizi xinjiaozhu 韓非子新校注 [New Collation and Exegeses on the Master Han Fei]. Shanghai: Shanghai guji chubanshe.

Chen, Qiyou 陳奇猷, ed. 2001. Lüshi chunqiu xinjiaoshi 呂氏春秋新校釋 [New Collation and Exegeses on the Annals of Sire Lü]. Shanghai: Shanghai guji chubanshe.

Chen, Lai 陳來. 2006. Gudai sixiang wenhua de shijie 古代思想文化的世界 [The World of Ancient Thought and Culture]. Taipei: Yunchen wenhua gongsi.

Chen, Lai 陳來. 2009. Gudai zongiiao yu lunli 古代宗教與倫理 [Ancient Religion and Ethics]. Beijing: Joint Publishing.

Chen, Minzhi 陳旻志. 2009. “Chengti jigan de wenhua yuanxing yu shengwu guanshe zhi tankan” 誠體寂感的文化原型與聖巫關涉 之探勘 [Study on the Cultural Prototype of cheng's Resonance and Its Relationship with the Sage-Shaman]. Zhexue yu wenhua 哲 學與文化 [Philosophy and Culture] 36: 103-28.

Chen, Wei 陳偉, ed. 2009. Chudi chutu Zhanguo jiance shisizhong 楚地出土戰國簡册十四種 [Fourteen Warring-States Bamboo Manuscripts Excavated from Chu]. Beijing: Jingji kexue chubanshe.

Csikszentmihalyi, Mark. 2009. Ethics and Self-Cultivation Practice in Early China. In Early Chinese Religion, Part One: Shang through Han (1250 BC-220 AD). Edited by John Lagerwey and Marc Kalinowski. Leiden: Brill, pp. 519-42.

Ding, Shan 丁山. 1956. Jiaguwen suojian shizu jiqi zhidu 甲骨文所見氏族及其制度 [Clans and Institutions as Seen in the Oracle Bone Inscriptions]. Beijing: Science Press.

Fan, Wenlan 范文瀾, ed. 1958. Wenxin diaolong zhu 文心雕龍注 [Annotation on the Embellishments of the Heart of Literature]. Beijing: Renmin wenxue chubanshe.

Guo, Moruo 郭沫若, ed. 1979-1983. Jiaguwen heji 甲骨文合集 [General Collection of Oracle Bone Inscriptions]. Beijing: Zhonghua Book Company.

Harper, Donald. 1999. Warring States Natural Philosophy and Occult Thought. In The Cambridge History of Ancient China: From the Origins of Civilization to 221 B.C.. Edited by Michael Loewe and Edward L. Shaughnessy. Cambridge: Cambridge University Press, pp. 813-84.

Hawkes, David. 1985. The Songs of the South: An Ancient Chinese Anthology of Poems by Qu Yuan and Other Poets. London and New York: Penguin Books.

He, Ning 何寧, ed. 1998. Huainanzi jishi 淮南子集釋 [Collected Exegeses on the Master Huainan]. Beijing: Zhonghua Book Company.

$\mathrm{Hu}$, Jixuan 胡吉宣, ed. 1989. Yupian jiaoshi 玉篇校釋 [Collation and Exegeses on the Jade Volume]. Shanghai: Shanghai guji chubanshe.

Huang, Zongxi 黃宗羲 (1610-1695), ed. 1846. Song-Yuan xue'an 宋元學案 [The Records of Song-Yuan Scholars], 1846 ed.

Huang, Hui 黃暉, ed. 1990. Lunheng jiaoshi 論衡校釋 [Collation and Exegeses on the Doctrines Weighed]. Beijing: Zhonghua Book Company.

Huang, Huaixin 黃懷信, ed. 1995. Yi Zhoushu huijiao jizhu 逸周書匯校集注 [Collected Collations and Exegeses on the Remnant Zhou Documents]. Shanghai: Shanghai guji chubanshe.

Huang, Huaixin 黃懷信, ed. 2004. Heguanzi huijiao jizhu 鶡冠子匯校集注 [Collected Collations and Exegeses on the Master of the Pheasant Cap]. Beijing: Zhonghua Book Company.

Eric Hutton, trans. 2014, Xunzi: The Complete Text. Princeton: Princeton University Press.

Ji, Zhichang 紀志昌. 2000. “Cheng yu zhaijie: Cong jili dao zhexue de zhuanhua” 誠與齋戒: 從祭禮到哲學的轉化 [Cheng and Fast: The Transformation From Sacrificial Ritual to Philosophy]. Zhexue yu wenhua 哲學與文化 [Philosophy and Culture] 27: 1084-92.

Knoblock, John, and Jeffrey Riegel. 2000. The Annals of Lü Buwei: A Complete Translation and Study. Stanford: Stanford University Press.

Kong, Anguo 孔安國 (156 BCE-74 BCE), and Yingda Kong 孔穎達 (574-648), eds. 2000. Shangshu zhengyi 尚書正義 [Correct Meanings of the Book of Documents]. Beijing: Peking University Press.

Lai, Kehong 來可泓, ed. 2000. Guoyu jijie 國語集解 [Collected Exegeses on the Discourses of the States]. Shanghai: Fudan University Press.

Lao, Sze-Kwang 勞思光. 2001. Daxue ji Zhongyong yizhu xinbian 大學及中庸譯注新編 [Translation and Commentary on the Great Learning and Doctrine of the Mean: A New Compilation]. Hong Kong: Chinese University of Hong Kong Press.

Legge, James. 1994. The Chinese Classics. 4 vols. Taipei: SMC Publishing.

Li, Jingde 黎靖德, ed. 1986. Zhuzi yulei 朱子語類 [Classified Discourses of Zhu Xi]. Beijing: Zhonghua Book Company.

Li, Ling 李零. 1993. “Baoshan Chujian yanjiu (zhanbulei)” 包山楚簡研究 (占卜類) [Study on the Chu Bamboo Manuscripts from Baoshan (Category of Divination)]. Zhongguo dianji yu wenhua luncong 中國典籍與文化論叢 [Study on Chinese Texts and Culture] 1: 435-45.

Li, Zehou 李澤厚. 1999. “Shuo wu-shi chuantong” 說巫史傳統 [On the Shaman-Historian Tradition]. In Jimao wushuo 己卯五說 [Five Essays from 1999]. Beijing: Zhongguo dianying chubanshe.

Li, Xueqin 李學勤. 2000. “Qin yudu suoyin” 秦玉牘索隱 [Study on the Jade Plaque of Qin]. Palace Museum Journal 2: 41-45.

Li, Ling 李零. 2006a. Zhongguo fangshu zhengkao 中國方術正考 [Formal Study on Chinese Recipes and Techniques]. Beijing: Zhonghua Book Company. 
Li, Ling 李零. 2006b. Zhongguo fangshu xukao 中國方術續考 [Subsequent Study on Chinese Recipes and Techniques]. Beijing: Zhonghua Book Company.

Lian, Shaoming 連劭名. 2001. “Qin Huiwenwang daoci Huashan yujianwen yanjiu” 秦惠文王禱祠華山玉簡文研究 [Study on the Jade Plaque Text of King Huiwen of Qin's Sacrifice to Mount Hua]. Zhongguo lishi bowuguan guankan 中國歷史博物館館刊 [Journal of the Museum of Chinese History] 1: 49-57.

Mcleod, Alexus. 2018. The Philosophical Thought of Wang Chong. London: Palgrave Macmillan.

Mou, Zongsan 牟宗三. 1984. Zhongguo zhexue de tezhi 中國哲學的特質 [Essential Features of Chinese Philosophy]. Taipei: Taiwan xuesheng shuju.

Munro, Donald. 1988. Images of Human Nature. Princeton: Princeton University Press.

Paper, Jordan. 1995. The Spirits Are Drunk: Comparative Approaches to Chinese Religion. Albany: State University of New York Press.

Qiu, Xigui 雸錫圭. 1978. “Hanzi xingcheng wenti de chubu tansuo” 漢字形成問題的初步探索 [Initial Discussions on the Issue of the Formation of Chinese Writing]. Zhongguo yuwen 中國語文 [Chinese Philology] 3: 165-66.

Sato, Masayuki 佐藤將之. 2005. “Zhanguo shidai cheng gainian de xingcheng yu yiyi” 戰國時代誠概念的形成與意義 [The Formation and Implications of the Concept cheng in the Warring States Period]. Tsinghua Journal of Chinese Studies 35: 215-44.

Shandong Province Museum 山東省博物館. 1972. “Shandong Yidu Suhutun yihao nulü xunzangmu” 山東益都蘇埠屯一號奴隸殉葬 墓 [Tomb No. 1 of Immolated Slaves in Suhutun of Yidu County in Shandong Province]. Wenwu 文物 [Cultural Relics] 8: 17-30.

Shen, Pei 沈培. 2007. “Cong Zhanguojian kan guren zhanbu de bizhi: Jianlun yisui shuo” 從戰國簡看古人占卜的蔽志: 兼論移崇說 [Interpreting the "Bad Intention" and "Removing the Ghosts" according to Warring States Bamboo Manuscripts]. Guwenzi yu gudaishi 古文字與古代史 [Paleography and Ancient History] 1: 391-434.

$\mathrm{Su}$, Bingqi 蘇秉琦. 1994. Huaren, long de chuanren, Zhongguoren 華人, 龍的傳人, 中國人 [Hua People, Descendants of the Dragon, Chinese People]. Shenyang: Liaoning University Press.

Sukhu, Gopal. 2012. The Shaman and the Heresiarch: A New Interpretation of the Li Sao. Albany: State University of New York Press.

Sun, Yirang 孫詒讓, ed. 2001. Mozi xiangu 墨子間詁 [Annotation on the Master Mo Di]. Beijing: Zhonghua Book Company.

Tang, Lan 唐蘭. 1977. “Cong Dawenkou wenhua de taoqi wenzi kan woguo zuizao wenhua de niandai” 從大汶口文化的陶器文字 看我國最早文化的年代 [From the Dawenkou Culture See the Time of the Earliest Writings of Our Nation]. Guang Ming Daily, July 14 .

Wang, Pinzhen 王聘珍, ed. 1983. Dadai Liji jiegu 大戴禮記解詁 [Annotation on Dai De's Records of Ritual]. Beijing: Zhonghua Book Company.

Wang, Xianqian 王先謙, ed. 1988. Xunzi jijie 荀子集解 [Collected Annotations on the Xunzi]. Beijing: Zhonghua Book Company.

Wang, Yunxi 王運熙, and Yisheng Gu 顧易生. 2001. Zhongguo wenxue pipingshi xinbian 中國文學批評史新編 [History of Chinese Literary Criticism: A New Compilation]. Shanghai: Fudan University Press.

Wang, Bi 王㢱 (226-249), and Yingda Kong, eds. 2000. Zhouyi zhengyi 周易正義 [Correct Meanings of the Book of Changes]. Beijing: Peking University Press.

Xu, Shen 許慎. 1963. Shuowen jiezi 說文解字 [Explanations of Simple Graphs and Analyses of Complex Characters]. Beijing: Zhonghua Book Company.

Xu, Fuguan 徐復觀. 2009. Zhongguo renxinglun shi: Xianqin pian 中國人性論史: 先秦篇 [A History of the Chinese Theory of Human Nature: Pre-Qin Volume]. Taipei: Taiwan shangwu yinshuguan.

Xu, Zhongshu 徐中舒, ed. 1998. Jiaguwen zidian 甲骨文字典 [Dictionary of Oracle Bone Inscriptions]. Chengdu: Sichuan cishu chubanshe.

Yates, Robin. 1997. Five Lost Classics: Tao, Huang-Lao, and Yin-Yang in Han China. New York: Ballantine Books.

Yu, Chenglong 于成龍. 1999. “Baoshan erhao Chumu bushijia zhong ruogan wenti de tantao” 包山二號楚墓卜筮簡中若干問題的探 討 [Study on Several Issues Concerning the Divinatory Bamboo Manuscripts from the No. 2 Tomb at Baoshan]. Chutu wenxian yanjiu 出土文獻研究 [Study on Excavated Texts] 5: 163-73.

Zhang, Dainian 張岱年. 1983. Zhongguo zhexueshi fangfalun fafan 中國哲學史方法論發凡 [Introduction to the Methodology of Chinese Philosophical History]. Beijing: Zhonghua Book Company.

Zheng, Xuan (127-200), and Gongyan Jia 賈公彥, eds. 2000a. Yili zhushu 儀禮注疏 [Exegeses on the Classic of Ritual]. Beijing: Peking University Press.

Zheng, Xuan, and Gongyan Jia 賈公彥, eds. 2000b. Zhouli zhushu 周禮注疏 [Exegeses on the Ritual of Zhou]. Beijing: Peking University Press.

Zheng, Xuan, and Yingda Kong, eds. 2000. Liji zhushu 禮記注疏 [Exegeses on the Records of Ritual]. Beijing: Peking University Press.

Zheng Zhang, Shangfang 鄭張尚芳. 2003. Shanggu yinxi 上古音系 [Ancient Phonetic System]. Shanghai: Shanghai jiaoyu chubanshe.

Zhong, Zhixiang 鐘志翔. 2013. “Yi Wenyan xiuci licheng lun yuanjie” 易文言修辭立誠論原解 [Interpretation of the Thesis of Refining Writings to Establish Sincerity in the "Words of the Text" Commentary on the Book of Changes]. Zhouyi yanjiu 周易研究 [Study on the Book of Changes] 5: 12-20.

Zhou, Xunchu 周勛初. 1986. Jiuge xinkao 九歌新考 [New Study on the Nine Songs]. Shanghai: Shanghai guji chubanshe.

Zhou, Fengwu 周鳳五. 2001. “Qin Huiwenwang daoci Huashan xintan” 秦惠文王禱祠華山新探 [New Study on King Huiwen of Qin's Sacrifice to Mount Hua]. Bulletin of the Institute of History and Philology Academia Sinica 72: 217-32.

Zhu, Xi 朱喜 (1130-1200). 1992. Sishu zhangju jizhu 四書章句集注 [Collected Exegeses on the Four Books]. Beijing: Zhonghua Book Company. 